\title{
Effect of Return On Assets, Return On Equity and Earning Per Share on the price of shares at PT. Gajah Tunggal tbk
}

\author{
Ilham \\ Sekolah Tinggi Ilmu Ekonomi YPN Karawang \\ Email: ilham.balanipa@gmail.com
}

(Received: January 20-2020; revised: April 23-2020; published: June 30-2020)

\begin{abstract}
This study aims to determine the effect of Return on Assets, Return on Equity and Earning Per Share on stock prices at PT. Gajah Tunggal Tbk. The method used was explanatory research with a sample of 8year financial statements in the form of a panel PT. Gajah Tunggal Tbk. The analysis technique uses statistical analysis with regression testing, correlation, determination and hypothesis testing. The results of this study Return on Assets have a significant effect on stock prices by $53.4 \%$, hypothesis testing obtained significance of $0.040<0.05$. Return on Equity has a significant effect on stock prices by $83.0 \%$, hypothesis testing obtained significance of $0.002<0.05$. Earning Per Share has a significant effect on the stock price of $97.9 \%$, the hypothesis test obtained significance $0,000<0.05$. Return on Assets, Return on Equity and Earning Per Share simultaneously have a significant effect on the stock price of $99.5 \%$, the hypothesis test obtained significance $0,000<0.05$.
\end{abstract}

Keywords: Return on Asset; Return on Equity; Earning Per Share; Stock price

\section{INTRODUCTION}

Firm is an organization that combines and organizes various resources with the aim of producing goods and services for sale (Ali et al., 2018; Della Torre, 2019; Ren \& Jackson, 2020; Tzabbar et al., 2017). The company's goal is to maximize the value of the company and the welfare of its shareholders. Maximizing shareholder value can be achieved by maximizing the present value or present value of all shareholder profits that are expected to be obtained in the future (Shi et al., 2020; VanDalsem, 2019).

Stock price as an indicator to measure the success of a company's management, where market power on the stock market is indicated by the sale and purchase of the company's shares in the capital market (Cao et al., 2002; Dunford et al., 2010; Fu et al., 2020 ; Yin et al., 2020). The transaction conditions and conditions are based on investors' observations of the company's achievements in increasing profits. Shareholders who are dissatisfied with management's performance can sell their shares and invest their money in other companies (Sunarsi et al., 2019; Sunarsi \& Kusjono, 2019). If this is done, it will reduce the stock price of a company (Astuti \& Husna, 2020).

Share price is the present value of income to be received by investors in the future (Bennett et al., 2020). The stock price shows the achievements of companies that move in the direction of the company's performance. Companies that have good achievements can improve their company performance which is reflected in the company's financial statements, so investors will be interested in investing in the company. Increasing investor demand for these companies will cause the price of the company's shares to tend to increase as well (Jati, 2019). 
174 |Jurnal Ilmiah Ilmu Administrasi Publik: Jurnal Pemikiran dan Penelitian Administrasi Publik Volume 10 Number 1, January - June 2020. Page 173-182

The company's financial statements can be a reference for investors in making investment decisions, such as selling, buying, or investing in shares. Stock prices can change at any time depending on the amount of supply and demand of investors for these shares. Factors that can affect the ups and downs of a company's stock price are internal factors and external factors of the company. This study uses company internal factors as reflected in the company's financial statements (Afriyanti et al., 2020; Jati, 2019; Kencana, 2020; Tumanggor, 2020). The company's internal factors are used in the form of financial ratios such as profitability ratios that are proxied by Return on Assets (ROA), Return on Equity (ROE) and market ratios that are proxied by Earning Per Share (EPS).

Return on Assets (ROA) is a profitability ratio that measures how much a company can increase a company's net profit by using all assets owned by the company. The greater ROA shows that the profit or profit achieved by the company is greater, so that it will attract investors to invest their capital in the company. The increasing demand for these shares will later be able to increase the price of the company's shares in the market. Research conducted by Pradipta (2012) found that ROA had a positive and significant influence on stock prices in LQ-45 companies on the Indonesia Stock Exchange in the 2009-2011 period. While research Murtiningsih (2010) states that ROA has no influence on stock prices in Food and Beferage Companies on the Stock Exchange.

Return on Equity (ROE) is a ratio that is used to measure the level of net income earned by a company for the capital invested. The greater the ROE ratio illustrates the better the state of the company, so that it will increase investor confidence to invest their capital. Nurfadilah (2011) states that ROE has a significant effect on stock prices.

Earning Per Share (EPS) is a market ratio used to measure how much market recognition a company has by comparing net income with the number of shares outstanding on the market. The increasing EPS indicates that the company has succeeded in increasing investor prosperity by dividend distribution. This can increase investor demand for shares which in turn will also increase the company's stock price. Research conducted by Shubiri (2010), found that partially EPS has a significant positive effect on stock prices at Commercial Banks in Jordan. In contrast to research conducted by Iqbal Khan (2010), found that EPS has a negative and not significant effect on stock prices in the Chemical and Pharmaceutical Industry.

The author chooses Return on Asset (ROA) and Return on Equity (ROE) ratios as factors that affect stock prices, because Return on Assets (ROA) and Return on Equity (ROE) are ratios that represent the taking of all company activities. While Earning Per Share (EPS) was chosen because EPS shows how many rupiahs of profit investors receive on each share. These three variables are thought to be considerations of investors in buying shares and having a profit can affect the stock price. The following is the value of ROA, ROE, and EPS on the Share Price of PT. Gajah Tunggal Tbk can be seen in Table 1. 
Table 1

Value of Return on Assets (ROA), Return on Equity (ROE) and Earning Per Share (EPS) on the Share Price of PT Unilever Tbk

Tahun 2011-2018.

\begin{tabular}{|c|c|c|c|c|}
\hline Year & $\begin{array}{c}\text { Return On } \\
\text { Asse }\end{array}$ & $\begin{array}{c}\text { Return on } \\
\text { Equity } \\
\text { (ROE) }\end{array}$ & $\begin{array}{c}\text { Earning every } \\
\text { Share (EPS) }\end{array}$ & $\begin{array}{c}\text { Share Price } \\
\text { (Rp) }\end{array}$ \\
\hline 2011 & 52.94 & 104.79 & 257 & 6.750 \\
\hline 2012 & 55.63 & 115.23 & 315 & 7.800 \\
\hline 2013 & 52.77 & 111.74 & 339 & 11.050 \\
\hline 2014 & 54.44 & 112.27 & 444 & 16.500 \\
\hline 2015 & 56.73 & 151.45 & 546 & 18.800 \\
\hline 2016 & 52.03 & 162.98 & 534 & 20.850 \\
\hline 2017 & 58.36 & 168.25 & 702 & 26.000 \\
\hline 2018 & 58.76 & 166.93 & 712 & 28.300 \\
\hline
\end{tabular}

Based on calculations and graph above shows that the Return on Assets (ROA) in the last 8 years (year 2011 until the year 2018 ) showed a fluctuating development where there is a decrease caused by the lack of ability of the company to generate profits. And an increase that indicates increasingly attractive investor interest in investing their capital. Based on the background above, this is the background of the writers interested in conducting research on "The Effect of Return on Assets (ROA), Return on Equity (ROE) and Earning Per Share (EPS) on the Share Price of PT. Gajah Tunggal Tbk "

\section{METHOD}

The population in this study 8 years financial statements in the form of PT. Gajah Tunggal Tbk . The sampling technique in this study is saturated sampling, where all members of the population are sampled. Thus the sample in the 8 year financial statement research in the form of PT. Gajah Tunggal Tbk. The type of research used is associative, where the aim is to find out the connection between. In analyzing the data used instrument test, classical assumption test, regression, coefficient of determination and hypothesis testing.

\section{RESULT AND DISCUSSION}

\section{Descriptive Analysis}

In this test used to determine the highest minimum and maximum scores, ratting scores and standard deviations of each variable. The results are presented in table 2 . 
176 Jurnal Ilmiah Ilmu Administrasi Publik: Jurnal Pemikiran dan Penelitian Administrasi Publik Volume 1o Number 1, January - June 2020. Page 173-182

Table 2

Descriptive Statistics Analysis Results

Descriptive Statistics

\begin{tabular}{|l|r|r|r|r|r}
\hline & N & Minimum & Maximum & \multicolumn{1}{c}{$\begin{array}{c}\text { The } \\
\text { mean }\end{array}$} & Std. Deviation \\
\hline Return o n Assets (X1) & 8 & 52.03 & 58.76 & 55,0200 & 2,60562 \\
\hline Return on Equity (X2) & 8 & 104.79 & 168.25 & 136,7050 & 28.07259 \\
\hline Earning Per Share (X3) & 8 & 257.00 & 712.00 & 481.1250 & 172,58574 \\
\hline Stock Price (Y) & 8 & 6.75 & 28.30 & 17,0063 & 8.03659 \\
\hline Valid N (listwise) & 8 & & & & \\
\hline
\end{tabular}

Return on Assets obtained a minimum variance of $52.03 \%$ and a maximum variance of $58.76 \%$ with a ratting score of 55.02 with a standard deviation of $2.605 \%$. Return on Equity obtained a minimum variance of $104.79 \%$ and a maximum variance of $168.25 \%$ with a ratting score of $136.70 \%$ with a standard deviation of $28.072 \%$. Earning Per Share obtained a minimum variance of $257.00 \%$ and a maximum variance of $712.00 \%$ with a ratting score of $481.12 \%$ with a standard deviation of $172.58 \%$. The stock price obtained a minimum variance of 6.7 and a maximum variance of 28.30 with a ratting score of 17,006 with a standard deviation of 8.036.

\section{Verification Analysis}

This analysis is intended to determine the effect of independent variables on the dependent variable. The test results are presented in multiple linear regression analysis. This regression test is intended to determine changes in the dependent variable if the independent variable changes. The test results are presented in table 3.

Table 3

Multiple Linear Regression Testing Results

\section{Coefficients $^{\text {a }}$}

\begin{tabular}{|c|c|c|c|c|c|}
\hline \multirow[b]{2}{*}{ Model } & \multicolumn{2}{|c|}{$\begin{array}{l}\text { Unstandardized } \\
\text { Coefficients }\end{array}$} & \multirow{2}{*}{$\begin{array}{c}\text { Standardized } \\
\text { Coefficients } \\
\text { Beta }\end{array}$} & \multirow[b]{2}{*}{$\mathrm{t}$} & \multirow[b]{2}{*}{ Sig. } \\
\hline & B & $\begin{array}{l}\text { Std. } \\
\text { Error }\end{array}$ & & & \\
\hline $\begin{array}{ll}\quad \text { (Constant) } \\
\end{array}$ & 34,973 & 11,979 & & 2,920 & .043 \\
\hline Return o n Assets (X1) & -725 & .218 & -.235 & $-3,319$ & .029 \\
\hline Return on Equity (X2) & -069 & .033 & -242 & -2.113 & 102 \\
\hline Earning Per Share (X3) & .065 & .007 & 1,402 & 9,474 & .001 \\
\hline
\end{tabular}

a. Dependent Variable: Share Price (Y)

Based on the test results in the above table, the regression equation $\mathrm{Y}=34.973-0.725$ $\mathrm{X} 1-0.069 \mathrm{X} 2+0.065 \mathrm{X} 3$ is obtained. From the equation explained as follows: 
1) A constant of 34.973 means that if there is no Return on Assets, Return on Equity and Earning Per Share, then there is a stock price of 34.973 points.

2) Return on Asset regression coefficient of -0.725 , this number is negative meaning that every time there is a decrease in Return on Assets of -0.725 points, the share price will also decrease by -0.725 points.

3) Return on Equity regression coefficient of -0.069 , this number is negative meaning that every time there is a decrease in Return on Equity of - 0.069 points, the share price will also decrease by -0.069 points.

4) Earning Per Share regression coefficient of 0.065 , this number is positive meaning that every time there is an increase in Earning Per Share by 0.065 points, the share price will also increase by 0.065 points.

\section{Hypothesis testing}

\section{Partial hypothesis test ( $t$ test)}

Hypothesis testing with $\mathrm{t}$ test is used to find out which partial hypotheses are accepted. First Hypothesis: There is a significant effect between Return on Assets on stock prices.

Table 4

Hypothesis Test Results Return on Assets Against Stock Prices.

\begin{tabular}{|c|c|c|c|c|c|}
\hline \multirow[b]{3}{*}{ Model } & \multicolumn{5}{|c|}{ Coefficients ${ }^{a}$} \\
\hline & \multicolumn{2}{|c|}{$\begin{array}{c}\text { Unstandardized } \\
\text { Coefficients }\end{array}$} & \multirow{2}{*}{$\begin{array}{c}\text { Standardized } \\
\text { Coefficients } \\
\text { Beta }\end{array}$} & \multirow[b]{2}{*}{$\mathrm{t}$} & \multirow[b]{2}{*}{ Sig. } \\
\hline & B & Std. Error & & & \\
\hline (Constant) & $-106,955$ & 47,360 & & -2.258 & .065 \\
\hline Return On Asset (X1) & 2,253 & .860 & .730 & 2,620 & .040 \\
\hline
\end{tabular}

a. Dependent Variable: Share Price (Y)

Based on the test results in the above table, a significance value of $0.040<0.050$ is obtained, thus the first hypothesis proposed that there is a significant influence between Return on Assets on stock prices is accepted.

Table 5

Hypothesis Test Results Return on Equity Against Stock Prices.

Coefficients ${ }^{\text {a }}$

\begin{tabular}{llr|r|r|r|r}
\hline & \multicolumn{2}{c}{ Unstandardized } & \multicolumn{2}{c|}{$\begin{array}{c}\text { Standardized } \\
\text { Coefficients }\end{array}$} & & \\
Model & \multicolumn{2}{c}{ Coefficients } & & \\
\hline 1 & B & Std. Error & Beta & \multicolumn{1}{c}{ t } & Sig. \\
\hline & (Constant) & $-18,644$ & 6,712 & & -2.778 & .032 \\
\hline
\end{tabular}

a. Dependent Variable: Share Price (Y) 
178 Jurnal Ilmiah Ilmu Administrasi Publik: Jurnal Pemikiran dan Penelitian Administrasi Publik Volume 1o Number 1, January - June 2020. Page 173-182

Based on the test results in the table above, a significance value of $0.002<0.050$ is obtained, thus the second hypothesis is proposed that there is a significant influence between Return on Equity on stock prices received.

Table 6

Earning Hypothesis Test Results Per Share Against Stock Prices.

\section{Coefficients ${ }^{\text {a }}$}

\begin{tabular}{|c|c|c|c|c|c|}
\hline \multirow[b]{2}{*}{ Model } & \multicolumn{2}{|c|}{$\begin{array}{c}\text { Unstandardized } \\
\text { Coefficients }\end{array}$} & \multirow{2}{*}{$\begin{array}{c}\text { Standardized } \\
\text { Coefficients } \\
\text { Beta } \\
\end{array}$} & \multirow[b]{2}{*}{$\mathrm{t}$} & \multirow[b]{2}{*}{ Sig. } \\
\hline & B & Std. Error & & & \\
\hline 1 (Constant) & $-5,162$ & 1,395 & & $-3,700$ & .010 \\
\hline Earning Per Share (X3) & .046 & .003 & 899 & 16,760 & .000 \\
\hline
\end{tabular}

a. Dependent Variable: Share Price (Y)

Based on the test results in the table above, a significance value of $0,000<0.050$ is obtained, thus the third hypothesis proposed that there is a significant influence between Earning Per Share on stock prices is accepted.

\section{Simultaneous Hypothesis Test (Test F)}

Hypothesis testing with the F test is used to find out which simultaneous hypotheses are accepted. The fourth hypothesis There is a significant influence between Return on Assets, Return on Equity and Earning Per Share on stock prices.

Table 7

Hypothesis Test Results Return on Assets, Return on Equity and Earning Per Share on Stock Prices.

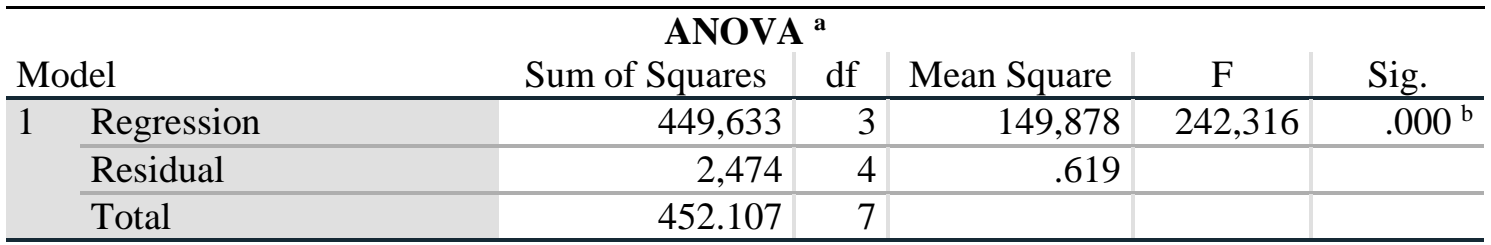

a. Dependent Variable: Share Price (Y)

b. Predictors: (Constant), Earning Per Share (X3), Return On Assets (X1), Return on Equity (X2)

Based on the test results in the above table, a significance value of $0,000<0.050$ is obtained, thus the fourth hypothesis is proposed that there is a significant influence between Return on Assets, Return on Equity and Earning Per Share on the price of shares received. 


\section{Discussion}

Return on Assets has a significant effect on stock prices with a correlation of 0.730 or has a strong relationship with a contribution of $53.4 \%$. Hypothesis testing obtained a significance value of $0.040<0.050$. Thus the first hypothesis proposed that there is a significant effect between Return on Assets to the stock price received. Return on Equity has a significant effect on stock prices with a correlation of 0.911 or has a strong relationship with an influence contribution of $83.0 \%$. Hypothesis testing obtained a significance value of $0.002<0.050$. Thus the second hypothesis is proposed that there is a significant effect between Return on Equity and the stock price received.

Earning Per Share has a significant effect on stock prices with a correlation of 0.989 or has a strong relationship with a contribution of $97.9 \%$. Hypothesis testing obtained a significance value of $0,000<0.050$. Thus the third hypothesis is proposed that there is a significant effect between Return on Equity on stock prices received. Return on Assets, Return on Equity and Earning Per Share have a significant effect on stock prices by obtaining a regression equation $\mathrm{Y}=34.973-0.725 \mathrm{X} 1-0.069 \mathrm{X} 2+0.065 \mathrm{X} 3$, the correlation value of 0.995 or has a strong relationship with the contribution of influence of $99.5 \%$ while the remaining $5.0 \%$ is influenced by other factors. Hypothesis testing obtained a significance value of 0,000 $<0.050$. Thus the fourth hypothesis proposed that there is a significant effect between Return on Assets, Return on Equity and Earning Per Share on the share price received.

\section{CONCLUSION}

Return on Assets has a significant effect on stock prices with an effect contribution of $53.4 \%$. Hypothesis testing obtained a significance value of $0.040<0.050$. Return on Equity has a significant effect on stock prices with an influence contribution of $83.0 \%$. Hypothesis testing obtained a significance value of $0.002<0.050$. Earning Per Share has a significant effect on stock prices with an influence contribution of $97.9 \%$. Hypothesis testing obtained $t$ value $>t$ table or (8.550> 1.989). Return on Assets, Return on Equity and Earning Per Share have a significant effect on stock prices with an influence contribution of $99.5 \%$ while the remaining $5.0 \%$ is influenced by other factors. Hypothesis testing obtained a significance value of 0,000 $<0.050$.

\section{REFERENCES}

Afriyanti, R., Daraba, D., \& Kasmita, M. (2020). Implications of Shrimp Crackers Empowerment Industry on Community Welfare. PINISI Discretion Review, 1(2), 97-102.

Ali, M., Lei, S., \& Wei, X.-Y. (2018). The mediating role of the employee relations climate in the relationship between strategic HRM and organizational performance in Chinese banks. Journal of Innovation \& Knowledge, 3(3), 115-122. https://doi.org/https://doi.org/10.1016/j.jik.2016.12.003

Astuti, E. P., \& Husna, F. M. (2020). The Effect of Net Interest Margin (NIM) and Operational Costs Operating Income (BOPO) on Return on Assets (RoA) at PT. Bank Rakyat 
180 |Jurnal Ilmiah Ilmu Administrasi Publik: Jurnal Pemikiran dan Penelitian Administrasi Publik Volume 10 Number 1, January - June 2020. Page 173-182

Indonesia, Tbk. PINISI Discretion Review, 2(1), 1-8.

Bennett, B., Stulz, R., \& Wang, Z. (2020). Does the stock market make firms more productive? Journal of Financial Economics, 136(2), 281-306. https://doi.org/https://doi.org/10.1016/j.jfineco.2019.09.006

Cao, F., Ye, K., Zhang, N., \& Li, S. (2002). Stock Price Distribution. Option Theory, 29(1), 2956. https://doi.org/doi:10.1002/0470013273.ch3

Della Torre, E. (2019). Collective voice mechanisms, HRM practices and organizational performance in Italian manufacturing firms. European Management Journal, 37(3), 398410. https://doi.org/https://doi.org/10.1016/j.emj.2018.09.001

Dunford, B. B., Boswell, W. R., \& Boudreau, J. W. (2010). When do high-level managers believe they can influence the stock price? Antecedents of stock price expectancy cognitions. Human Resource Management, 49(1), 23-43. https://doi.org/10.1002/hrm.20332

Fu, J., Wu, X., Liu, Y., \& Chen, R. (2020). Firm-specific investor sentiment and stock price crash risk. Finance Research 101442. https://doi.org/https://doi.org/10.1016/j.frl.2020.101442

Jati, W. (2019). The Effect of Financial Leverage, Operating Leverage and Current Ratio on Profitability at PT. Manunggal Persada Jakarta. PINISI Discretion Review, 3(2), 135-142.

Kencana, P. N. (2020). The Effect of Product Quality on Purchasing Decisions of Honda Motorized Vehicles with Matic Scooter Types. PINISI Discretion Review, 1(2), 81-88.

Ren, S., \& Jackson, S. E. (2020). HRM institutional entrepreneurship for sustainable business organizations. Human Resource Management Review, 30(3), 100691. https://doi.org/https://doi.org/10.1016/j.hrmr.2019.100691

Shi, J., Yu, C., Liu, X., \& Li, Y. (2020). Predicting firm stock returns with customer stock returns: Moderating effects of customer characteristics. Research in International Business and Finance, 101280. https://doi.org/https://doi.org/10.1016/j.ribaf.2020.101280

Sunarsi, D., \& Kusjono, G. (2019). Pengaruh Lingkungan Kerja Non Fisik, Konflik Dan Turn Over Intention Terhadap Produktivitas Kerja Karyawan Pada CV. Usaha Mandiri Jakarta Selatan. Jurnal Ekonomi Efektif, 1(3).

Sunarsi, D., Kustini, E., Lutfi, A. M., Fauzi, R. D., \& Noryani, N. (2019). Penyuluhan Wirausaha Home Industry Untuk Meningkatkan Ekonomi Keluarga Dengan Daur Ulang Barang Bekas. BAKTIMAS: Jurnal Pengabdian Pada Masyarakat, 1(4), 188-193.

Tumanggor, M. (2020). The Influence of Current Ratio, Quick Ratio and Net Profit Margin on Return on Assets at PT. Hero Supermarket Tbk. PINISI Discretion Review, 1(1), 137-146.

Tzabbar, D., Tzafrir, S., \& Baruch, Y. (2017). A bridge over troubled water: Replication, integration and extension of the relationship between HRM practices and organizational performance using moderating meta-analysis. Human Resource Management Review, 
Ilham; Effect of Return On Assets, Return On Equity and Earning Per Share ...| 181

27(1), 134-148. https://doi.org/https://doi.org/10.1016/j.hrmr.2016.08.002

VanDalsem, S. A. (2019). Sacrificing corporate investment for stock repurchases: Are family firms different? Journal of Economics and Business, 104, 105837. https://doi.org/https://doi.org/10.1016/j.jeconbus.2019.03.001

Yin, L., Wei, Y., \& Han, L. (2020). Firms' profit instability and the cross-section of stock returns: Evidence from China. Research in International Business and Finance, 53, 101203. https://doi.org/https://doi.org/10.1016/j.ribaf.2020.101203 
182 Jurnal Ilmiah Ilmu Administrasi Publik: Jurnal Pemikiran dan Penelitian Administrasi Publik Volume io Number 1, January - June 2020. Page 173-182 